O. Kuznietsov ${ }^{1}$, O. Kolomiitsev ${ }^{2}$, A. Kiyko ${ }^{1}$, A. Kovalchuk ${ }^{1}$, K. Sadovyi ${ }^{1}$

${ }^{1}$ Ivan Kozhedub Kharkiv National Air Force University, Kharkiv, Ukraine

${ }^{2}$ National Technical University "Kharkiv Polytechnic Institute", Kharkiv, Ukraine

\title{
ANALYSIS OF POSSIBILITIES OF PROVIDING OF NECESSARY EXACTNESS OF MEASURING OF SPATIAL COORDINATES OF AIR OBJECTS IN THE RADIO-LOCATION STATION OF ACCOMPANIMENT WITH PHASE AERIAL BY A GRATE
}

\begin{abstract}
Modern Phased-Array Antenna (PAA) radars are an effective mean of aerial reconnaissance and provide radar information on aerial objects in a complex environment. The subject of the article is the influence of the inhomogeneities of the troposphere and the earth's surface on the decrease in the accuracy of measurement of angular coordinates and altitude of air objects in radars with PAA. The purpose of the article is to numerically estimate the possible values of the root mean square error of measuring the angular coordinates and the height of air objects due to the influence of fluctuations of the phase edge of the radar wave. Task: analysis of possible mechanisms of origin and statistical characteristics of correlated phase fluctuations of a radio signal for a model of a signal with random amplitude and initial phase. Methods used: methods of probability theory and mathematical statistics. The following results were obtained. The estimation technique is developed and possible values of the mean-square errors of measurement of angular coordinates and altitude of air objects are obtained, which are caused by the influence of radar signal phase wave front fluctuations for the three-coordinate PAA radar of centimeter range. The above calculation method allows to carry out the numerical estimation of errors of measurement of angular coordinates and object height. Conclusions. This technique can be practically used in assessing the effect of real conditions of propagation and reflection of radar signal on the reduction of the capabilities of modern radars with PAA to perform tasks on purpose.
\end{abstract}

Keywords: phased array antenna; angular coordinates; height of air object; phase fluctuations; troposphere, earth surface; radio-location supervision.

\section{Introduction}

Formulation of the Problem in General. The use of high technology in radar technology stimulates the search for ways to develop radar systems. One of the promising directions of such development is the creation of multifunctional and multimode radars of the tracking type $[1,2]$.

A fundamental feature of the tracking radar type is that this radar class is designed to support airborne objects. This is complicated by the increasing speed and altitude of airborne objects and the presence of a wide range of interfering radiation. Such radar systems provide for the possibility of adaptation to a specific air environment, choice of the optimal mode of operation (type of sounding signal, antenna beam scanning method, signal processing method, etc.).

Multifunctional radars need to solve a number of real-time tasks: space inspection, detection of aerial objects, automated selection of aerial objects for tracking, switching to coordinate tracking, formation and maintenance of trajectories in difficult air and interference conditions. Such radars should use promising technical solutions: the use of PAA with electronically controlled beam headlamps, coherent signal processing using digital filtering, the use of sophisticated sounding signals.

Tracking radars function both according to external target data, such as from radar detection and offline search mode.

The tracking radar has requirements such as completeness of information about objects, speed of viewing space, high accuracy, necessity of accompaniment of several objects at the same time.
These requirements determine the use of phased array antennas in these radars.

The use of PAA in the modern tracking radar allows to obtain complete coordinate information on many objects simultaneously with its automatic issuance to the consumer.

In many PAA radars, angular measurements are provided by the phase method, that is, phase shifts of received signals in the PAA elements carry information about the spatial position of the target.

The real conditions for the propagation of a radar signal are the source of fluctuations in the phase edge of a radar signal in the PAA elements. Fluctuation data disrupts its spatial coherence and reduces the accuracy of measuring of the angular coordinates and target height. Thus, estimation of the possible decrease in the accuracy of measuring the spatial coordinates in the radar with PAA allows to determine the degree of limitation of the quality of tracking of radar objects.

Analysis of Recent Research and Publications. Statistical characteristics of phase fluctuations arising from the influence of the Earth's atmosphere are analyzed in [2-6].

Mechanism of the occurrence of the angular noise of the target due to the wandering of its radar center and consequent phase fluctuations of the radar signal are described in $[2,7,8]$.

As a result of the impact on the radar of the terrestrial or marine surface, an interference phenomenon occurs, the features of which were considered in $[4,7,9,10]$.

Issues of organization of spatial measurements in the conditions of the influence of phase fluctuations in the propagation of radio waves on the coastal direction 
are considered in [11]. Assumptions about statistical characteristics of the reflected signals are confirmed by the results of the experimental study, which are covered in [12].

Regarding the measurement of the angular coordinates of the target in the radar with PAA in the conditions of fluctuations of the phase edge of the wave of the received signal, [13] offers a method for estimating the error of measuring the angle of arrival of a signal for different laws of change of the correlation coefficient of phase fluctuations. The relevant evaluation results are given in [14].

Numerical analysis of the influence of radar wave front fluctuations on the accuracy of measuring the angular coordinates and the target height in a tracking radar with PAA by means of the indicated technique represents the practical benefit.

The purpose of the article is to numerically estimate the possible values of the root mean square error of measuring of the angular coordinates and the height of air objects caused by the influence of fluctuations of the phase edge of the radar wave.

\section{Basic material}

In radars with PAA, determination of the angular coordinates of the targets is based on the measurement of the angular position of the reflected edge of the reflected electromagnetic wave relative to the receiving aperture.

Most often, the phase-based method of measuring the angular coordinates is used in the PAA radar. Information on the angular coordinate is contained in the phase difference of the oscillations of adjacent receiving channels (elements) [1,2]. That is, the phase method of measuring the angular coordinates lies in the determination of the direction of arrival of the electromagnetic wave front relative to the initial (reference) direction.

The angular coordinate of the target $\theta_{c}$ in relation to the equal-phase direction is determined according to the expression:

$$
\theta_{c}=\arcsin \frac{\psi_{0} \lambda}{2 \pi d}
$$

where $\psi_{0}$ - phase onset between adjacent receiving channels; $\lambda$ - radar wavelength; $d$-distance between the adjacent elements of PAA.

In this case, the wave front reflected from the aerial object in the distance $r>>d$ is considered as flat.

By installing the appropriate phase shifts in the PAA reception channels for each expected value of the signal arrival angle from a predetermined range, it is possible to move (scan) the antenna pattern in space. In this case, the maximum of the amplitude of the signal at the output of the PAA is provided in case of arrival of electromagnetic wave from the direction of the target.

Radar sounding signals propagate in the Earth's atmosphere. Turbulence of the atmosphere leads to fluctuations in its refractive index. In the troposphere, for frequencies not exceeding $20 \mathrm{GHz}$, the refractive index is determined by the expression [5]

$$
n=1+\frac{77,6 \cdot 10^{-4}}{T}\left(P+\frac{4810 \rho}{T}\right),
$$

where $T$ - absolute temperature; $P$ - atmosphere pressure; $\rho$ - absolute humidity.

According to (2), fluctuations of pressure, temperature and humidity in the troposphere lead to fluctuations in the refractive index and, as a result, fluctuations in the phase of the radio signal propagating through the ball and turbulent tropospheric inhomogeneities. Fluctuations of the refractive index of the troposphere are locally homogeneous, isotropic, random field in the interval of spatial scales from millimeters to hundreds of meters.

According to [3], the variance value of the refractive index fluctuations is within:

$$
\sigma_{n}^{2}=0,25 \cdot 10^{-12} \ldots 0,25 \cdot 10^{-10} \text {. }
$$

Thus, when the signal is propagated in the atmosphere, it can be modulated by a random law, which can be interpreted as a modulating (multiplicative) interference.

In case of a large number of statistically independent inhomogeneities in the region essential for the propagation of radio waves, then, by the central limit theorem, phase and level fluctuations are distributed according to the normal law.

With the assumption of geometric optics, the Gaussian form of the correlation coefficient of the refractive index of the medium, according to [2], expression for the dispersion $\sigma_{\varphi}^{2}$ of phase fluctuations of the signal passing the troposphere has the following form:

$$
\sigma_{\varphi}^{2}=0,1 \cdot C_{\varepsilon}^{2} k^{2} z L_{0}^{5 / 3}
$$

where $C_{\varepsilon}^{2}=2 \sigma_{\varepsilon}^{2} / L_{0}^{2 / 3}$ - structural constant; $\sigma_{\varepsilon}^{2}-$ dispersion of fluctuations of the dielectric constant of the troposphere; $L_{0}$ - external scale of the troposphere turbulence; $k=2 \pi / \lambda$ - wave number; $z$ - path of the wave in the troposphere.

If the whole line is in a randomly inhomogeneous medium, then the expression for the radius of correlation of phase fluctuations is determined as follows:

$$
\rho_{\varphi}=\left(11 \cdot C_{\varepsilon}^{2} z / \lambda^{2}\right)^{-3 / 5}
$$

For the troposphere with an outer scale $L_{0}$ close to $1 \mathrm{~km}$, the square value of the structural constant varies from $10^{-13} \mathrm{~cm}^{2 / 3}$ in the lower layers to $10^{-18} \mathrm{~cm}^{2 / 3}$ in the upper layers and practically does not depend on frequency [2].

Numerical values of the dispersion of phase fluctuations are determined by the external scale and intensity of inhomogeneities $L_{0}$.

As shown in [2], for the non-excited troposphere at the external scale of the inhomogeneity $L_{0} \approx 1 \mathrm{~km}$, for the route $z \approx 100 \mathrm{~km}$, and the wavelength $\lambda=1 \mathrm{~cm}$, the 
standard deviation of the phase fluctuations of the signal is $\sigma_{\varphi} \approx 2 \pi$. Given the dependences on the wavelength $\sigma_{\varphi} \equiv \lambda^{-1}$, it follows that phase fluctuations in the troposphere are significant for centimeter and shorter waves. It is in the centimeter range of wavelengths that the radar of the tracking type usually works.

Provided that the entire track is in a randomly inhomogeneous medium, the radius of coherence in the troposphere for the given data is $\rho \approx 40 \mathrm{~m}$, while the regularity is $\rho \equiv \lambda^{6 / 5}$.

For tracking radar the detection range of targets with an effective dispersion area of $1 \mathrm{~m}^{2}$ can be $100 \ldots 200 \mathrm{~km}$ with conditional probabilities of correct detection $D=0,9$ and false alarm $F=10^{-6}$ [1].

Magnitudes of the dispersion and correlation radius of phase fluctuations calculated according to expressions (3) and (4) for $C_{\varepsilon}^{2}=10^{-13}, \lambda=5 \mathrm{~cm}$, $L_{0}=1 \mathrm{~km}$ and different values of $z=50,100,150$ and $200 \mathrm{~km}$ are shown in Table 1.

Table 1 -Magnitudes of the dispersion and correlation radius of phase fluctuations

\begin{tabular}{|c|c|c|c|c|}
\hline$z, \mathrm{~km}$ & 50 & 100 & 150 & 200 \\
\hline$\sigma_{\varphi}^{2}, \mathrm{rad}^{2}$ & 17 & 34 & 51 & 68 \\
\hline$\rho_{\varphi}, \mathrm{m}$ & 98,8 & 65,2 & 51,1 & 23,3 \\
\hline
\end{tabular}

We consider a case when the law of distribution of phase fluctuations is close to normal and the correlation function is approximated by exponential dependence.

Decrease in the quality of angular measurements is significantly affected by the Earth's surface. The real reflection surface is not perfectly flat. The degree of "equality" is determined by the ratio between the wavelength and the geometric parameters of inequalities.

The propagation of the propagating electromagnetic wave and its reflection from the Earth's surface give rise to changes in the signal parameters, the nature of which is difficult to predict.

Field at the point of reception is formed by the interference of a large number of scattered waves resulting in chaotic changes in the amplitude and phase of the signal. Fluctuations of these parameters cause additional components of the measurement of the angular coordinates of the target. Errors of multipath propagation are particularly significant at low target heights.

In case of multipath propagation of the radar signal $[4,7]$, dispersion of phase fluctuations can reach more than a dozen $\operatorname{rad}^{2}$ for centimeter waves, and the radius of correlation of phase fluctuations can be at $\rho_{\varphi}=(140 \ldots 160) \lambda$ at $z=45 \ldots 50 \mathrm{~km}$.

In [4], errors of measurement of the angular coordinates of the target obtained in radial scanning radar and beamwidth of the antenna operating at a frequency of $2797 \mathrm{MHz}$ at an antenna height of about $45 \mathrm{~m}$ are presented. The maximum values of the error of measurement of the angle of the place of the target reach $2 \ldots 2,5^{\circ}$.

Azimuth measurement errors can be tenths of a degree and are partly caused by true azimuth measurement errors at small angles of space, which depend on surface irregularities, and partly by crosslinks in the radar, since it is impossible to completely eliminate the relationship between the azimuth detection schemes and seats.

In [13] it is stated that when receiving a coherent signal with a randomly distributed initial phase and a random Rayleigh amplitude against the background of internal noise, dispersion of the angular coordinate estimation error for PAA with uniform amplitude distribution is described by the expression:

$$
\frac{1}{\sigma_{\theta}^{2}}=\frac{q^{2}\left(4 m^{2}-1\right)}{12}\left(\frac{2 \pi d}{\lambda}\right)^{2},
$$

where $\theta$ - expected angle of arrival of a signal calculated from the normal to the aperture of PAA;

$$
\begin{aligned}
& q^{2}-\text { signal to noise ratio in power; } \\
& m=n / 2-\text { number of pairs of symmetric PAA }
\end{aligned}
$$
(counting is from the center of the PAA);

$$
n \text { - number of PAA elements. }
$$

It is assumed that phase fluctuations are distributed according to the normal law with zero mean and variance $\sigma_{\varphi}^{2}$.

The coefficient of inter-channel correlation of phase fluctuations of signals can be described by the exponential dependence:

$$
K(d)=e^{-d / \rho},
$$

where $\rho$ - radius of correlation of phase fluctuations for adjacent PAA elements.

As shown in [13], for the coefficient of interchannel correlation of phase fluctuations (6), the corresponding expression for the variance of the fluctuation component of the error of measuring the angle of arrival of the signal is:

$$
\begin{gathered}
\sigma_{\theta f l}^{2}=\frac{9 \sigma_{\varphi}{ }^{2} \lambda^{2}}{2 \pi^{2} d^{2} m^{2}\left(4 m^{2}-1\right)^{2}} \times \\
\times\left[\sum_{j=1}^{m}(2 j-1)^{2} \cdot\left(1-\exp \left(-\frac{d}{\rho}(2 j-1)\right)\right)+\right. \\
+2 \sum_{l=1}^{m-j} \exp \left(-l \frac{d}{\rho}\right) \cdot \sum_{j=1}^{m-1}\left(\left(1-\exp \left(-\frac{d}{\rho}(2 j-1)\right)\right)\right] .
\end{gathered}
$$

Expression (7) makes it possible to numerically evaluate the effect of phase fluctuations of the signal arising from atmospheric heterogeneities and the Earth's surface on the decrease in the accuracy of measuring the angular coordinates of a target in a radar with PAA [14]. 
Peculiarity of radar tracking is the presence in their composition of automation systems in the distance, speed, azimuth and angle of the place. Depending on the radar mode (search, tracking, query, etc.), appearance or parameters of the signal may change.

In a tracking radar, in addition to tracers, nontracking measuring devices can be used. This is necessary to ensure targeting of tracking systems in target or manual guidance modes.

Thus, the modern airborne tracking radar is a multifunctional radar, which is a three-coordinate, centimeter-centimeter-coil pulsed radar with PAA.

This type of antenna system is able to realize a quick and high-precision change in both the spatial position of the radiation pattern and the appearance of this diagram.

The phased antenna array forms a radiation pattern that has a beam width of $0,7 \ldots 0,9^{\circ}$ [1].

Tracking radars can operate autonomously or externally and provide automatic detection, capture and tracking of multiple aerodynamic objects.

In this case, to realize space inspection at the angle of the place, the beam can be sequentially moved electronically with the measurement of the angle of the target by the phase method.

In this case, the principle of measuring the angle of location is based on the determination of the vertical inclination of the wave created by the signal reflected from the target.

It is believed that an electromagnetic wave reflected from the target at an angle of location $\varepsilon$ is incident on the vertical antenna array with the same pitch of the elements. As the target is at a distance far exceeding the size of the antenna system, the wave front is considered flat.

Signals in different receiving channels of the PAA will have phase shifts $\psi_{i}$ relative to the first channel, the values of which allow to determine the angle of the target location:

$$
\varepsilon_{t}=\arcsin \frac{\psi_{i} \lambda}{2 \pi(i-1) d} .
$$

After determining the angle of the target, the height of the target can be calculated.

The target height is calculated according to the Earth's curvature and normal tropospheric refraction according to the expression:

$$
H_{t}=D_{t} \sin \varepsilon_{t}+\frac{D_{t}^{2}}{2 R_{e E}}+h_{a},
$$

where $D_{t}$ - target distance; $R_{e E}$ - equivalent radius of the Earth; $h_{a}$ - height of antenna installation.

The root mean square error of the measurement of the angle of the target $\sigma_{\varepsilon}$ can be converted to the mean square error of the height measurement $\sigma_{H}$ using expression (9) [15].

Values of the mean square error measurement of the height of the air object, depending on the variance of random phase distortions of the signal $\sigma_{\varphi}^{2}$ at an antenna height of $8 \mathrm{~m}$ obtained for ranges of $50 \mathrm{~km}, 100 \mathrm{~km}$, 150 and $200 \mathrm{~km}$ are given in Table 2 .

Table 2 - Values of the mean square error measurement of the height of the air object

\begin{tabular}{|c|c|c|c|c|}
\hline$\sigma_{\varphi}^{2}, \mathrm{rad}^{2}$ & 17 & 34 & 51 & 68 \\
\hline$\rho, \mathrm{m}$ & 98,8 & 65,2 & 51,1 & 23,3 \\
\hline$\sigma_{H 0}, \mathrm{~m}$ & 8,9 & 9,8 & 10,6 & 11,5 \\
\hline$\sigma_{H 1}, \mathrm{~m}$ & 169,7 & 568,4 & 1167,3 & 2617,1 \\
\hline
\end{tabular}

Results are obtained for the following input data: $m=50 ; \quad \lambda=5 \mathrm{~cm} ; \quad q^{2}=100 ; \quad d=\lambda / 2 ; \quad h_{a}=8 \mathrm{~m}$; $\sigma_{\varphi}^{2}=17, \quad 34,51,68 \mathrm{rad}^{2}$; the phase fluctuation correlation radius assumes appropriate values $\rho=98,8,65,2,51,1,23,3 \mathrm{~m}$.

In the Table 2, the values of the mean square error measuring the height of the target correspond to the following cases: $\sigma_{H 0}-$ no influence of phase fluctuations (due to the influence of the internal noise of the receiving device only); $\sigma_{H 1}$ - influence of phase fluctuations with the exponential form of the interchannel correlation coefficient.

As can be seen, with the increase in the variance of random phase distortions of the mean square error, height measurement increases by tens to hundreds of times compared to the effect of the internal noise of the receiver only.

That is, at distances of $50 \ldots 200 \mathrm{~km}$ of the mean square error, measuring the height of the target $\sigma_{H}$ can reach values from hundreds of meters to units of kilometers while changing the correlation of phase fluctuations according to the exponential law.

The values of the mean square error of measuring the angular coordinate of the radar object in a vertical or horizontal plane calculated from normal to the aperture of the PAA for the above conditions are given in Table 3 .

Table 3 - The values of the mean square error of measuring the angular coordinate of the radar object in a vertical or horizontal plane

\begin{tabular}{|c|c|c|c|c|}
\hline$\sigma_{\varphi}^{2}, \operatorname{rad}^{2}$ & 17 & 34 & 51 & 68 \\
\hline$\rho, \mathrm{m}$ & 98,8 & 65,2 & 51,1 & 23,3 \\
\hline$\sigma_{\theta f l}^{\circ}$ & 0,18 & 0,32 & 0,44 & 0,75 \\
\hline$\sigma_{\theta f l} / \sigma_{\theta}$ & 3 & 5,3 & 7,3 & 12,5 \\
\hline
\end{tabular}

This Table shows the values of the mean square error measurement of the angular coordinate $\sigma_{\theta f l}$ due to the influence of phase fluctuations of the signal in the 
elements of the PAA only, and the ratio $\sigma_{\theta f l} / \sigma_{\theta}$ of this mean square error to the value of the mean square error measurement of the angular coordinate $\sigma_{\theta} \approx 0,06^{\circ}$, subject to the influence of the internal noise of the receiving radar device only.

It follows from the obtained results that in tracking radar the fluctuation error of measuring the angular coordinates of the objects of radar surveillance can several times exceed the corresponding potential measurement error.

Thus, the lack of consideration of phase fluctuations of the signal in its spatial processing is the cause of significant errors in the measurement of the angular coordinates and the height of the target in the radar with the PAA. In this case, the spatial coordinate estimates are not suitable for use as targets to provide consistent tracking of airborne objects.

\section{Conclusions and directions of further research}

The above calculation method allows to carry out numerical estimation of errors of measurement of angular coordinates and target height. This technique can be practically used in assessing the impact of real conditions of propagation and reflection of radar signal on the reduction of the capabilities of modern radars with PAA to perform tasks on purpose.

Areas of further research are: improvement of modern PAA with signal processing in the direction of optimization of the existing spatial measurement algorithms [16-22].

\section{REFERENCES}

1. Sedyshev, Yu.M. (2010), Radioelectronic systems, Kharkiv, 418 p.

2. Shirman, Ya.D. (1999), Radioelectronic systems, Z.A.O. „MAKVISC”, Moscow, 828 p.

3. Shifrin, Ya.S. (1970), Statistical antenna theory issues, Sov. radio, Moscow, 383 p.

4. Krasyuk, N.P. (1988), The influence of the troposphere and underlying surface on the radar's work, Radio and communication, Moscow, $223 \mathrm{p}$.

5. Dolukhanov, M.P. (1971), Fluktuation processes in the propagation of radio waves, Communication, Moscow, $183 \mathrm{p}$.

6. Petrushenko, M.M. (2009), "Features of the use of radio systems of the Air Force in unstable hydrometeorological conditions and natural meteorological phenomena", Navigation and communication control systems, No. 2 (10), pp. 54-57.

7. Skolnik, M. (1976), Radar Reference Guide, Sov. radio, Moscow, 456 p.

8. Ostrovityanov, R.V. and Basalov, F.A. (1982), The statistical theory of radar extended targets, Radio and communication, Moscow, $232 \mathrm{p}$.

9. Fainberg, E.L. (1999), Propagation of radio waves along earth surface, Science, Moscow, 496 p.

10. Kotov, A.F. (1992), "The influence of reflections from the underlying surface on the process of location of objects", Theory and practice of synchronization systems, pp. 4-8.

11. Karlov, V.D., Petrushenko, N.N., Chelpanov, V.V. and Kvitkin, K.P. (2010), "The influence of the propagation medium of radio waves in the coastal direction in measuring the angular coordinates of the radar targets", Scientific Works of Kharkiv Air Force University, No. 3 (25), pp. 51-53.

12. Karlov, V.D., Rodyukov, A.O. and Pichugin, I.M. (2015), "Statistical characteristics of radar signals are reflected from local objects in conditions of abnormal refraction", Science and Technology of the Air Force of Ukraine, No. 4 (21), pp. 71-74.

13. Kuznietsov, O.L. (2008), "Estimation of the influence of phase fluctuation of a signal on a decrease in the accuracy of measuring the angular coordinates of the target in a radars with phased antenna arrays", Information processing systems, No. 1 (68), pp. 38-40.

14. Kuznietsov, O.L., Tantsyura, O.B. and Melnik, O.L. (2012), "The limitation of the quality of spatial measurement in a radar with a phased antenna array due to the influence of atmospheric inhomogeneities and the earth surface", Navigation and communication control systems, No. 1 (21), pp. 49-52.

15. Kuznietsov, O.L. (2015), "Estimation of the optimization efficiency of spatial processing of a radar signal in a radar with a phased antenna array", Information processing systems, No. 12 (37), pp. 30-33.

16. Shirman, Ya.D. and Manzhos, V.N. (1981), Theory and technology of processing radar information against the background noise, Radio and communication, Moscow, $416 \mathrm{p}$.

17. Sedyshev, Yu.M., Karpenko, V.I. and Atamanskiy, D.V. (2010), Radioelectronic systems, KhUPS, Kharkiv, 418 p.

18. Mozhaev O. Multiservise network security metric / O. Mozhaev, H. Kuchuk, N. Kuchuk, M. Mozhaev, M. Lohvynenco // IEEE Advanced information and communication technologies-2017. Proc. of the 2th Int. Conf. - Lviv, 2017. - P. 133-136. DOI: https://doi.org/10.1109/AIACT.2017.8020083

19. Ruban, I. Redistribution of base stations load in mobile communication networks / I. Ruban, H. Kuchuk, A. Kovalenko // Innovative technologies and scientific solutions for industries. -2017 . - No 1 (1) - P. 75-81. - DOI : https://doi.org/10.30837/2522-9818.2017.1.075

20. Svyrydov, A., Kuchuk, H., Tsiapa, O. (2018), "Improving efficienty of image recognition process: Approach and case study", Proceedings of 2018 IEEE 9th International Conference on Dependable Systems, Services and Technologies, DESSERT 2018, pp. 593-597, DOI: http://dx.doi.org/10.1109/DESSERT.2018.8409201

21. Kuznietsov, O.L, Kolomiitsev, O.V. and Sadovyi, К.V. (2017), "Distinction after way distance РЛС with the synthesized aerial by a grate in the conditions of influence of not homogeneity atmosphere", Collection of scientific works Ivan Kozhedub Kharkiv Air Force University, Kharkiv, No. 2(51), pp. 130-133.

22. Aloshin, G.V. and Kolomiytsev, A.V. (2015), "Optimal choice of parameters of radio-location signals on the conditional criterion of a maximum of economic efficiency", The Informatively-managing systems are on a railway transport, Kharkiv, No. 6, pp. 3-7. 
ВідОмості ПРо АВторів / АвоUт тHE AUTHORS

Кузнєцов Олександр Леонідович - кандидат технічних наук, доцент, професор кафедри, Харківський національний університет Повітряних Сил імені Івана Кожедуба, Харків, Україна;

Oleksandr Kuznietsov - Candidate of Technical Sciences, Associate Professor, Professor of the Department, Ivan Kozhedub Kharkiv National Air Force University, Kharkiv, Ukraine; e-mail: SAG 2121@ukr.net; ORCID ID: https://orcid.org/0000-0002-5915-8107.

Коломійцев Олексій Володимирович -доктор технічних наук, старший науковий співробітник, начальник кафедри Військового інституту танкових військ, Національний технічний університет «ХПІ», Харків, Україна;

Oleksii Kolomiitsev - Doctor of Technical Sciences, Senior Research, Chief of department Military Institute of Tank Troops, National Technical University «Kharkiv Polytechnic Institute», Kharkiv, Ukraine; e-mail: Alexus_k@ukr.net; ORCID ID: https://orcid.org/0000-0001-8228-8404.

Кійко Андрій Сергійович - кандидат фізико-математичних наук, доцент кафедри, Харківський національний університет Повітряних Сил імені Івана Кожедуба, Харків, Україна;

Andriy Kiyko - Candidate of Physical and Mathematical Sciences, Associate Professor of the Department, Ivan Kozhedub Kharkiv National Air Force University, Kharkiv, Ukraine; e-mail: andriy.kiyko@gmail.com, ORCID ID: https://orcid.org/0000-0003-0786-4234.

Ковальчук Андрій Олексійович - кандидат технічних наук, старший науковий співробітник, доцент кафедри, Харківський національний університет Повітряних Сил імені Івана Кожедуба, Харків, Україна;

Andriy Kovalchuk - Candidate of Technical Sciences, Senior Research, Associate Professor of the Department, Ivan Kozhedub Kharkiv National Air Force University, Kharkiv, Ukraine; e-mail: Inna700nf@gmail.com; ORCID ID: https://orcid.org/0000-0003-1269-9368.

Садовий Костянтин Віталійович - кандидат технічних наук, доцент, заступник начальника кафедри, Харківський національний університет Повітряних Сил імені Івана Кожедуба, Харків, Україна;

Kostiantyn Sadovyi - Candidate of Technical Sciences, Associate Professor, Deputy Chief of the Department of Ivan Kozhedub Kharkiv National Air Force University, lieutenant colonel, Kharkiv, Ukraine; e-mail: 971sadovyi@gmail.com; ORCID ID: https://orcid.org/0000-0003-2703-9696.

Аналіз можливостей забезпечення необхідної точності вимірювання просторових координат повітряних об'єктів в радіолокаційній станції супроводження з фазованою антенною решіткою

О. Л. Кузнєцов, О. В. Коломійцев, А. С. Кійко, А. О. Ковальчук, К. В. Садовий

Анотація. Сучасні радіолокатори з фазованою антенною решіткою (ФАР) $є$ ефективним засобом повітряної розвідки та забезпечують отримання радіолокаційної інформації про повітряні об'єкти у складній обстановці. Предметом вивчення в статті $\epsilon$ вплив неоднорідностей тропосфери та земної поверхні на зниження точності вимірювання кутових координат та висоти повітряних об'єктів в радіолокаційних станціях (РЛС) з ФАР. Метою є чисельне оцінювання можливих значень середньоквадратичних похибок вимірювання кутових координат та висоти повітряних об'єктів, які обумовлені впливом флуктуацій фазового фронту хвилі радіолокаційного сигналу. Завдання: аналіз можливих механізмів виникнення та статистичних характеристики корельованих фазових флуктуацій радіосигналу для моделі сигналу 3 випадковою амплітудою та початковою фазою. Використані методи: теорії ймовірності та математичної статистики. Отримані наступні результати. Розроблено методику оцінювання та отримано можливі значення середньоквадратичних похибок вимірювання кутових координат та висоти повітряних об’ єктів, які обумовлені впливом флуктуацій фазового фронту хвилі радіолокаційного сигналу для трьохкоординатної РЛС сантиметрового діапазону з ФАР. Висновки. Наведена методика може бути практично використана при оцінюванні впливу реальних умов поширення і відбиття радіолокаційного сигналу на зниження можливостей сучасних РЛС з ФАР щодо виконання завдань за призначенням.

Ключ ов і сл ов а : фазована антенна решітка; кутові координати; висота повітряного об'єкту; фазові флуктуації; тропосфера; земна поверхня; радіолокаційне спостереження.

Анализ возможностей обеспечения необхоимой точности измерения пространственных координат воздушных объектов в радиолокационной станции сопровождения с фазированной антенной решеткой

А. Л. Кузнецов, А. В. Коломийцев, А. С. Кийко, А. А. Ковальчук, К. В. Садовый

Аннотация. Современные радиолокаторы с фазированной антенной решеткой (ФАР) являются эффективным средством воздушной разведки и обеспечивают получение радиолокационной информации об воздушных объектах в сложной обстановке. Предметом изучения в статье является влияние неоднородностей тропосферы и земной поверхности на снижение точности измерения угловых координат и высоты воздушных объектов в радиолокационных станциях (РЛС) с ФАР. Целью является численное оценивание возможных значений среднеквадратических ошибок измерения угловых координат и высоты воздушных объектов, которые обусловлены влиянием флуктуаций фазового фронта волны радиолокационного сигнала. Задача: анализ возможных механизмов возникновения и статистических характеристик коррелированных фазовых флуктуаций радиосигнала для модели сигнала со случайной амплитудой и начальной фазой. Используемые методы: теории вероятности и математической статистики. Получены следующие результаты. Разработана методика оценивания и получены возможные значения среднеквадратических ошибок измерения угловых координат и высоты воздушных объектов, которые обусловлены влиянием флуктуаций фазового фронта волны радиолокационного сигнала для трехкоординатной РЛС сантиметрового диапазона с ФАР. Выводы. Приведенная методика может быть практически использована при оценивании влияния реальных условий распространения и отражения радиолокационного сигнала на снижение возможностей современных РЛС с ФАР по выполнению задач по назначению.

Ключевые слов а: фазированная антенная решетка; угловые координаты; высота воздушного объекта; фазовые флуктуации; тропосфера; земная поверхность; радиолокационное наблюдение. 